\title{
GIS データによる寒冷地のダイレクトソーラーゲイン住宅の 設計判断に関する研究 \\ STUDY ON DESIGN METHOD OF HOUSING WITH DIRECT SOLAR HEAT GAIN BY USING GIS DATA IN COLD REGIONS
}

\author{
緒形浩佑 ${ }^{*}$, 森 太郎**, 大沢飛智***, 漬田裕章*** \\ 羽山広文 ${ }^{* * * *}$, 菊田弘輝 $* * * * *$ \\ Kosuke OGATA, Taro MORI, Hisato OSAWA, \\ Hiroaki HAMADA, Hirofumi HAYAMA and Koki KIKUTA
}

\begin{abstract}
It is important for planning an effect of direct solar gain to calculate the effect of surrounding environment, especially buildings around a numerical model. Therefore in this study, simulation of heating load with a boundary condition based GIS data was conducted. The result showed that solar heat gain was larger than heat loss from a window where Rss was larger than 0.4. The detail simulation were carried out for the building where Rss was larger than 0.4, and results revealed the relationship of glass size and heating load and interior design.
\end{abstract}

\author{
Keywords : Direct solar heat gain, GIS data, Southern sky factor, Thermal load calcu- \\ lation, Highly insulated house \\ ダイレクトソーラーダイン, GISデータ，南側天空率，熱負荷計算，高断熱住宅
}

\section{1. 研究の背景と目的}

日本におけるダイレクトソーラーゲイン（以下DSG）の研究は 昭和50年代からあり、蓄熱材に太陽光を効率よく吸収させるため に空形状や蓄熱材設置個所の検討が実験之解析の両面から小玉 ${ }^{11}$ 、 伊藤2)らによって進められてきた。伊藤らはDSGと補助暖房費の 関係性を明らかにしたが、これらの解析は建物の周辺環境を考慮し ない計算方法であり、空面から室内一侵入する日射量に影響を与 え、冷房負荷においては安全側、暖房負荷においては危険側の評価 となってしまう問題点があった。河合、浅輪ら $3^{3)}$ が建物外部の樹木 の有無がDSGや室温に与える影響を研究している。国外の最近の 例ではM.M.E.van Ech4) らは都市における建物の形状が変化する ことで、道路・壁面・屋根面に入射する日射量や暖房負荷を比較し

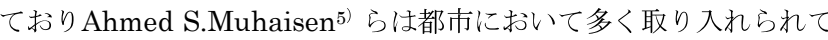
いる中庭の形、壁の高さによってDSG・冷房・暖房負荷がどの様 に変化するかを解析している。こうした研究背景の中で筆者らは GISデータを用い南鋁直面に侵入する日射量と天空率の関係を明ら かにした ${ }^{6)}$ 。本論はこの研究の延長として寒冷地における住宅の DSGの活用を検討したものである。

DSGとは、空から侵入する太陽光を暖房エネルギーとして利用 し暖房負荷を削減しようとする試みのことであり、DSGを考える
際に影響を及ぼす因子としては、空面積、ガラスの種類、室形状、 材質、断熱材厚さ、周辺建物の有無、地域別日射量の多宾等多岐に わたる。特に空は、日射を取得する主要な場所であると同時に熱の 大きな損失箇所でもある。この状態を安全側に考えると、高性能で 小さい空の設置というDSGを十分に活用しない設計判断がなされ る。そこで敷地選定の段階でDSGの恩恵をどの程度得られるかを知 ることが出来れば、企画の段階で設計にDSGを活用するか否かとい う決断を下すことが出来る。本研究の目的は寒冷地において、DSG を活用するか否かを決める最初の判断基準を提示すること、GISを 使用し周辺環境による熱取得の減少を考慮したDSG効果を考えるこ と、DSGを活用する際の設計条件が暖房負荷と室内の見え方に与え る影響についての検討である。GISを使用した周辺環境検討におい て周辺樹木の検討は議論が発散すると考え検討項目外とし、地域は 寒冷地の検討に焦点を絞った。室内の見え方はダイレクトソーラー ゲインに影響を与える内装色の状態を表している。住宅の居住者や 設計者によって好みが異なるため、室内の見え方と暖房負荷の関係 性を提示することは、DSGを活用して暖房エネルギーを削減するこ とと居住者の好む部屋の状態を作ることのどちらをどの程度優先さ せるか、という判断材料を提示することである。オフィスビルであ ればグレアや明るさ感を用いることも考えられるが、住宅において
* 株大林組 修十(口学)

** 北海道大学大学院工学研究院 准教授 ·博士 (工学)

$* * *$ 北海道大学大学院工学院 修士課程

**** 北海道大学大学院工学研究院 教授 ·博士 (工学)

$* * * * *$ 北海道大学大学院工学研究院 助教 $\cdot$ 博士 (工学)
Obayashi Corporation, M. Eng.

Assoc. Prof., Faculty of Eng., Hokkaido Univ., Dr. Eng.

Graduate Student, Graduate School of Eng., Hokkaido Univ.

Prof., Faculty of Eng., Hokkaido Univ., Dr. Eng.

Assist. Prof., Faculty of Eng., Hokkaido Univ., Dr. Eng. 
はそれらの指標よりもよりプライオリティが高いと考えられるた め、室内の見え方を因子として検討した。

DSGの設計判断は図1のフローチャートに従う。ある敷地に建物 を建設するとき、敷地の周囲には建物が存在し設計建物内に侵入す る日射量は気象データの值よりも周囲の建物による影響分減少す る。そこで十分日射の恩恵を受け、設計上DSG効果を引き出せる 敷地か否かの判断をDSG判定と定義した。DSGは空と壁面におけ る熱取得が熱損失を上回るときに有効であり、熱損失が熱取得を上 回るときは、高性能で小さい空を設置し熱損失を抑える設計が有効 である。次に、DSG判定によって是と判定された敷地においてガ ラスの大きさ、種類、壁面の色を因子に、判定よりも詳細な暖房負 荷解析を行い、各因子と暖房負荷と室内の見え方の関係をまとめ た。なお本研究において季節的な植生の変化は考慮していない。

\section{DSG判定}

\section{1 DSG判定の概要}

GISデータを基に敷地の周辺建物の影響を加味した日射データを 作成し、暖房負荷解析を行った。解析モデルの熱損失と熱取得のど ちらが上回るかを比べ、DSGを考えた設計が可能か否かの間值を 求めた。

\section{2 解析モデル}

高断熱住宅を想定した建物モデルを基に空面積やガラスの種類を 変更し暖房負荷解析を行った。作成したモデル外観と空面積の様子 を図2、構成を表 $1 、 3$ 種類の空ガラス実装時におけるQ值と外皮平 均熱貫流率 $U_{A}$ 值を表 2 に示す。空1かつペアガラスを実装したとき の $\mathrm{U}_{\mathrm{A}}$ 值は 0.449 、空3かつペアガラスを実装したときの $\mathrm{U}_{\mathrm{A}}$ 值は 0.228である。

\section{3 南側天空率と気象データ}

周囲の建物の影響を評価するために南側天空率（以下Rss）を使 用する。RssはGISデータ上で札幌の敷地を選択し、視点を天空方 向へ向け、周囲の建物を正射影方式で投影した魚眼画像の南側半円 における天空率である。Rssは值が大きいほど敷地南側が開けてお り、建物に遮られることなく日射が空面に侵入する。GISデータに は札幌市の都市計画基礎調査データを利用した。このデータは国土 地理院の基盤地図情報の建物データに市町村等が保有している建物 のデータベースを連結したもので、建物毎の敷地面積、延べ床面積 等を利用することが出来る。本報告ではデータベース内にある階数 のデータを利用し、 $1 \mathrm{~F} を 4 \mathrm{~m} 、 2 \mathrm{~F}$ 以上を $3 \mathrm{~m}$ とし建物の外形線を用 いて建物の概形を再現した。図3は札幌の住宅地において、GIS データを使用して求めた $\mathrm{Rss}_{\mathrm{s}}=0.4 、 0.5 、 0.7 、 0.90$ 敷地の正射影画 像である注1)。Rss=0.4の敷地は東側に建物があるため朝方に直達 光が室内に侵入せず、 $\mathrm{Rss}=0.9$ のときは周囲に建物が少ないため常 時直達光が侵入する。

\section{4 DSG判定における日射データ}

DSG判定の熱負荷解析用に周辺建物の影響を加味した日射デー 夕を作成した。具体的には札幌の標準年気象データ7)において前節 で述べた正射影画像に太陽位置を重祮合わせ、太陽が建物に隐れる 時間帯は直達日射量を $0 \mathrm{~W} / \mathrm{m}^{2}$ 、拡散日射量は天空率Rsを掛け合わ せた值を使用した。
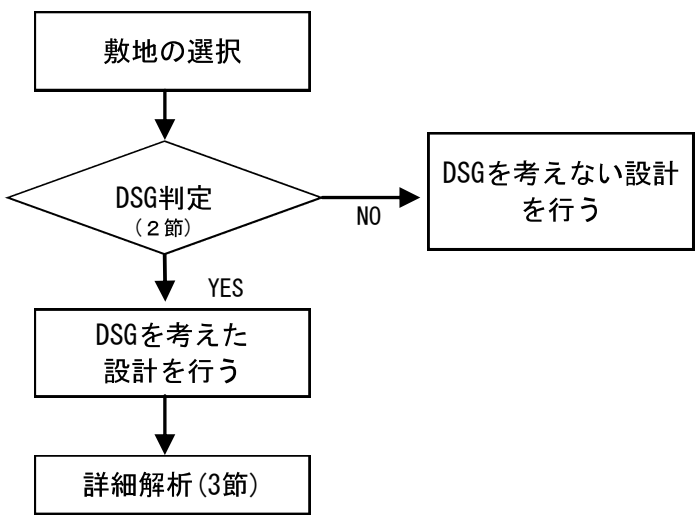

図1 フローチャート

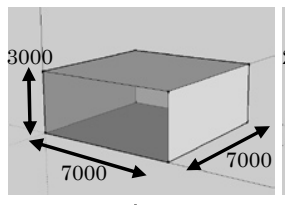

空 1

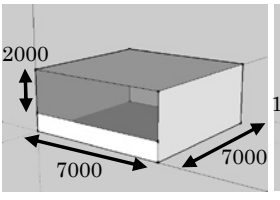

空2

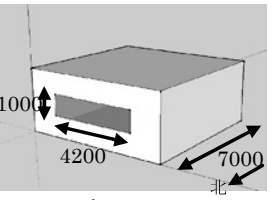

空3
図2 建物外観

表1 建物構成

\begin{tabular}{|c|c|}
\hline 場所 & 札幌市 \\
\hline ガラス条件、熱貫流率 [W/m² $\mathrm{K}$ ] & ペアガラス[2.9]、Low-eガラス[1.8] \\
\hline 建物基本形状 $[\mathrm{mm}]$ & 幅7000 奥行7000 天井高さ300 \\
\hline \multirow{3}{*}{ 㥶の形状[mm] } & 窓1 $7000 \times 3000$ \\
\hline & 窓 $27000 \times 2000$ \\
\hline & \begin{tabular}{l|l} 
窓3 & $4200 \times 1000$ \\
\end{tabular} \\
\hline 構成 $[\mathrm{mm}]$ & 外壁: GW120 床: 合板30 天井: GW400 \\
\hline 室内日射量解析ソフト & EnergyPlus Radiance \\
\hline 気象条件 & 夕1月1日～3月31日 \\
\hline
\end{tabular}

表2 熱損失係数、外皮平均熱貫流率

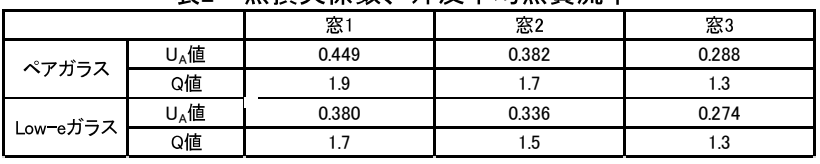

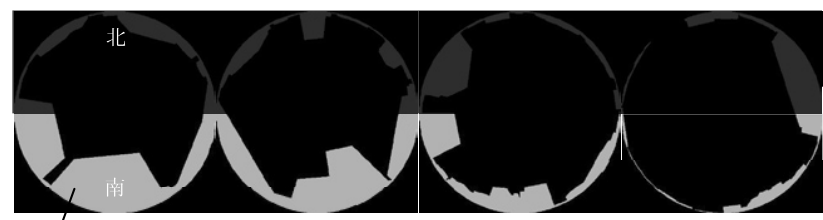

$/ \mathrm{Rss}=0.4$

$\mathrm{Rss}=0.5$

Rss $=0.7$

Rss $=0.9$

図3正射影画像による南側天空率

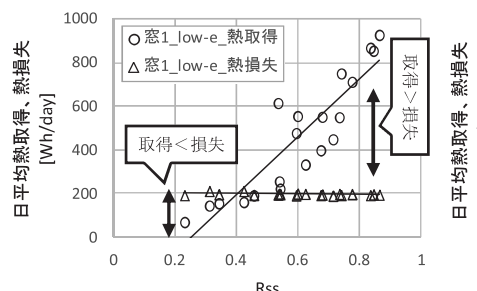

図4 空1

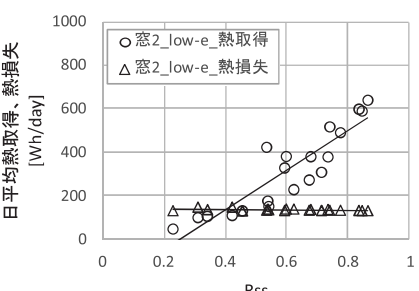

図5 空2

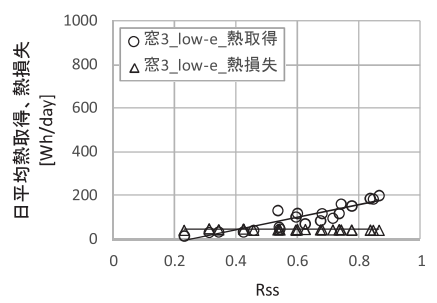

図6 空3 


\section{5 解析結果と閾値の算出}

暖房負荷解析にはEnergyPlus ${ }^{8)}$ を使用し、気象データは前節で 作成したデータを使用した。EnergyPlusの入力データは直達日射 量と拡散日射量であり、準直達日射量は直達日射量に含めて扱って いる。札幌市内においてRssの異なる20か所の敷地に空1-3の住宅 を設置し、厳冬期を想定して1月1日-3月31日の期間内で得られる 熱取得量と熱損失量の関係を表わしたものが図4-6である。図4は空 1を実装したモデルを示し、熱取得量についてはRssが大きくなる ほど熱取得量が増大し、熱損失量についてはRssの変化による変動 は小さい。図5と6は空 2 と空 3 を使用したモデルを示し、図 4 と比較 して近似曲線の傾きは小さくなるが傾向は一致した。3種の空全て において熱取得量と熱損失量の近似直線の交点が空の大きさに関わ らずRss約 0.4 であることが確認できる。図4-6のガラスの種類は Low-eガラスを使用しているが、ペアガラスを使用したケースも同 様の傾向を示した。このことからRssが 0.4 以上の敷地は熱取得量が 熱損失量を上回るため、DSGを使用した設計に適しており、Rssが 0.4以下の敷地はその逆となるためDSGを考えた設計に不適といえ る。その結果、札幌市ではRss=0.4がDSGを考えた設計が有効か否 かという閾值になることが分かった注2)。

\section{3. 詳細解析}

\section{1 詳細解析の概要}

前節より $\mathrm{Rss}=0.4$ がDSGの設計閾值であると判定できたので、本 節ではRssが0.4以上の敷地についてDSGを考慮した設計の詳細解 析を加えた。一般的に暖房負荷計算を行う際、日射侵入は空の性能 やブラインドの有無等の通過時の現象のみを考慮し、室内に侵入し た日射の一次入射日射量を各壁面に均等に分散させることで工学的 に近似出来ていると判断する。本節ではRadianceを使用し、ガラ スへの入射角度による透過率の減少、室内に侵入した日射の多重反 射、壁面の色の違いにより室外一出てゆく日射量の多宾、といった 精度の高い物理計算を考慮する解析を特徵としている。入射日射量 の解析にはGISデータを用いた周辺環境の影響、Birdモデル9)によ る波長別日射量を解析条件として使用し、RadianceのThree-phase methodを解析手法として使用した。壁面吸収日射量の解析はモデ ル壁面を110の面要素 (1面要素約 $1.7 \mathrm{~m}^{2}$ ) に分け面要素ごとの吸収 日射量求め、その後有限体積法により暖房負荷解析を行った。ま た、その際に各面要素間の長波長放射の影響も考虑した。以上の解 析手法からDSG効果を、壁面の色パターン、空面積、ガラスの種 類、熱容量の有無、を因子に暖房負荷、室内の見え方と比較した。 以下に詳細解析の手順を記す。

(1).GISデータを用いて周辺環境の再現

(2).Birdモデルを使用して日射を短波長・長波長に分離

(3).RadianceのThree-phase methodを用いて室内日射分布を算出

(4).110の面要素ごとに有限体積法を用いた室温・暖房負荷算出

\section{2 GISデータを用いた周辺環境の作成}

GISデータを用いてモデル周辺に建物を作成する際、モデルへの 入射日射量に影響する半径の閾值を求めた。作成モデルに近い距離 にある建物ほどモデルへの入射日射量に与える影響は大きく、遠い 距離にある建物ほど与える影響は小さい。よって、どの程度の範囲 の周辺建物を作成することが適当であるかを検討した。図7-9は作
成モデルを中心にRss別の周辺建物を作成し、上空から俯瞰した図 である。図10はRss0.86の敷地に図 11 のうな $1 \times 1 \times 10 \mathrm{~m}$ 、反射率 0.20 塔を中心に周辺建物を作成し、一例として標準年気象データ における札幌の 1 月 15 日（晴れ）の日射量を使用して塔の南面に入 射する日射量と高さの関係を、周辺建物の半径別にプロットした図 である。 $0 \mathrm{~m} は$ 周辺建物が存在しないケースであり、高さによらず 一定の日射量を示している。周辺 $100 \mathrm{~m}$ 以内の建物を作成したケー

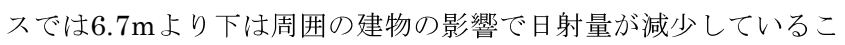
とが分かる。200mになるとさらに周囲の影響が顕著に表れ3.7、 $6.7 、 8.7 \mathrm{~m}$ の地点を境に塔に入射する日射量が変化している。 $300 \mathrm{~m}$ は $200 \mathrm{~m}$ と比べ変化がなく、西面の日射量、Rssの異なる敷地

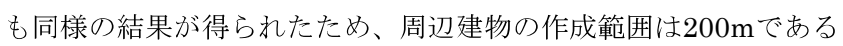
と結論付けた。GISデータを使用して作成した周辺建物情報を Radianceのモデル上に配置する際にも半径 $200 \mathrm{~m}$ 以内の建物を配置 することで室内への入射日射量への影響を抑えた。

\subsection{Birdモデルと標準年気象データ使用した波長別日射量の算出}

室内への日射侵入を考えるとき、空の波長別の透過率の違いに よって、侵入する日射量に大きな違いが表れる。このため可視域 (0.3-0.8 $\mathrm{\mu m})$ と近赤外域（0.8 $\mathrm{\mu m}$ 以上）を分けた解析を行った。 例えばペアガラスとLow`eガラスを比べると、断熱性能ではLow`e が優っているが日射熱取得率ではペアガラスが高い。こうした違い が室内への入射日射量分布や暖房負荷に与える影響を解析を通じ検 討した。図12は太陽放射の分光分布10)を示したものである。可視域

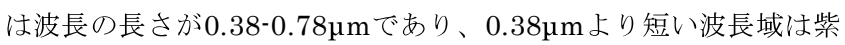

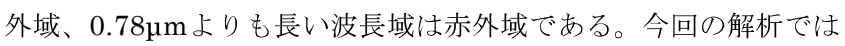

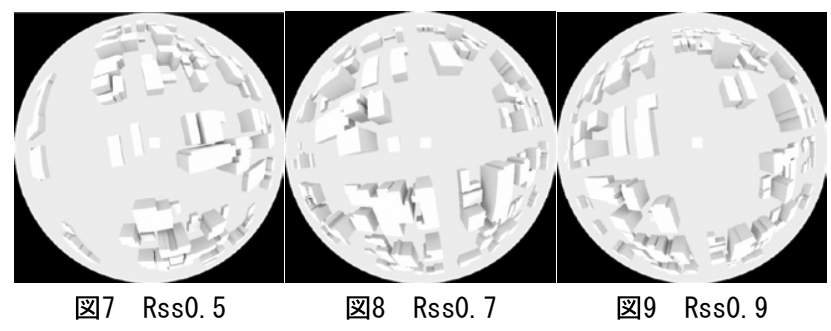

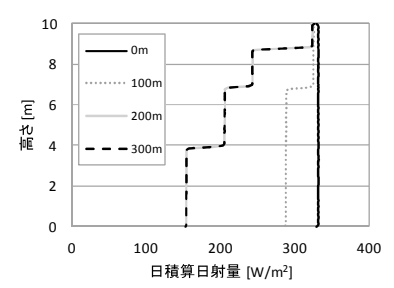

図10 南面日射量と高さ

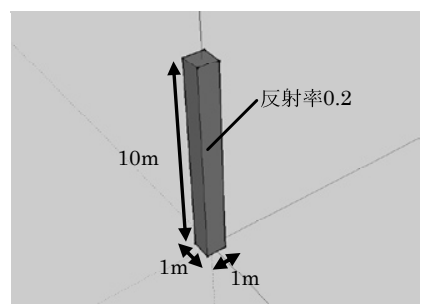

図11 中心に据えた塔

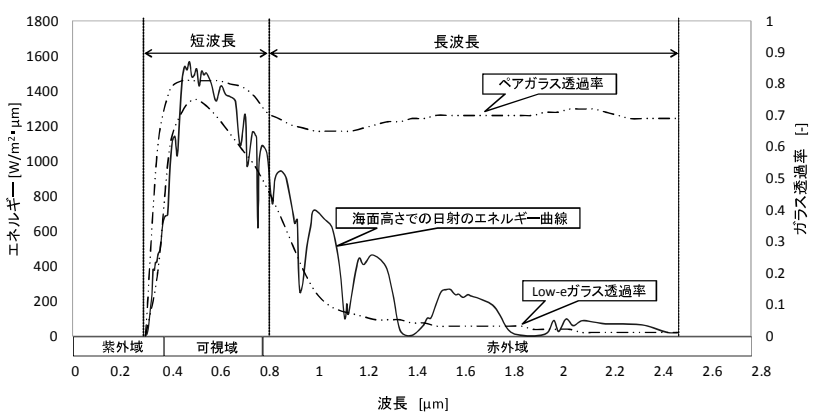

図12 太陽放射の分光分布 
可視域と近赤外域を分離して解析を行うため、0.3-0.8 $\mu \mathrm{m}$ 短波長

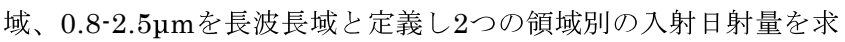
めた。標準年気象データから直達日射量と拡散日射量を得た後、そ れぞれをBirdモデルを使用し短波長領域と長波長領域に分離した （式（1）、（2））。

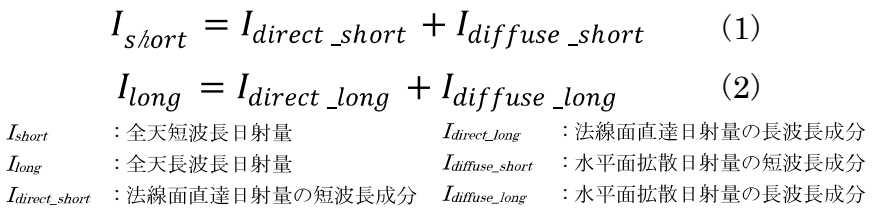
注) 単位は全て $\left[\mathrm{W} / \mathrm{m}^{2}\right]$

Birdモデルは大気圈外直達日射量に対し、エアロゾル減衰、オゾ ン吸収、水蒸気吸収による波長別の透過率を乗じて晴天時の法線面 直達日射量と水平面拡散日射量を求めるモデルである。日々刻々と エアロゾル量、オゾン量、水蒸気量は変化するため、標準年気象 データから正確な各值を知ることは難しい。本解析は冬季に限って いるため、オゾン厚さを $0.34 \mathrm{~cm}$ 、可降水量を $0.3 \mathrm{~cm}$ と固定した上で 計算を行った、Birdモデルと標準年気象データとの適合には、 Birdモデルのパラメーターの一つである波長500nmにおけるエア ロゾル光学的厚さ (Aerosol Optical Depth) を変化させ最適化を 試みた。最適化にはニュートンラプソン法を使用した。

\section{4 Three-phase method}

Three-phase methodはRadiance上で照度 - 昼光率 ・ 入射日射量 の年間計算を行う目的でつくられたツールである。従来の Radianceを用いてそれらを求める方法では、一観測点につき一回 ずつレイトレーシングを実施し侵入する日射の計算を行っており、 計算に多大な時間がかかる。Three-phase methodは従来の画像作 成の工程を行列計算に代表させることで計算時間を大幅に削減でき る。具体的には天空状態を簡易的に表わすため図13に示すような スカイパッチという分割方法を使用している。天空を145分割し、 一つ一つのパッチが占める面積内の日射を平均し天空を 145 点で表 している。その後、近隣建物を含めた外界と室内の関係、空の透過 率、スカイパッチから空面への影響、の3つの段階を行列で表わ し、掛け合わせることで観測視点に入射する日射量や照度を求める ことが出来る。この工程を式（3）で表わす。ここでiは入射日射 量、V(view matrix)は近隣の建物と室内の影響関係を表わ寸行列、 T(transmission matrix)は空の透過率を表わ寸行列、D(daylight matrix)はスカイパッチと空面の影響を表わ寸行列であり、s(sky vector)はスカイパッチの状態を表わ寸補助的な行列である ${ }^{11)} 145$ のスカイパッチに分割し、各面から放射される太陽光をレイトレー シングに使用することから、Three-Phase Methodを使用すること で準直達日射量の考えを含めた計算を行うことができる。

$$
\mathrm{i}=\text { VTDs }
$$

表3に入射日射量を算出する際に使用したガラスの透過率を示 す。図 12 に記したメーカーが公表しているガラス別の日射透過率 を参考に作成した。

Three-phase methodを用いて求めることの出来る分布図の一例 を図14に示す。図14の左図は空1装着時のモデルの展開図を110の 面要素に分割した図であり、右図は1月 2 日の10時を一例に110の面
要素に侵入する日射量を示したものである。ここでいう日射量とは 前節で作成した全天短波長日射量と全天長波長日射量を使用し、面 要素に侵入する日射量を波長域別に算出した後、足し合わせた值で ある。空側の床面と西壁に東側から日射が侵入し值が大きくなって いることが確認出来る。

従来の計算では波長域を分けないシングルバンドによって透過日 射量を評価しますが、3.1節から 3.4 節の手順に従い計算された日射

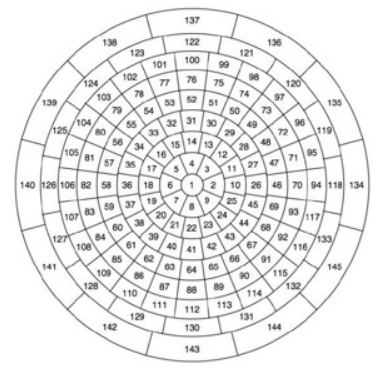

表3 ガラス透過率

\begin{tabular}{|c|c|c|}
\hline ガラス透過率 & 短波長 & 長波長 \\
\hline ペアガラス & 0.8 & 0.7 \\
\hline Low-eガラス & 0.5 & 0.2 \\
\hline
\end{tabular}

図13 スカイパッチ

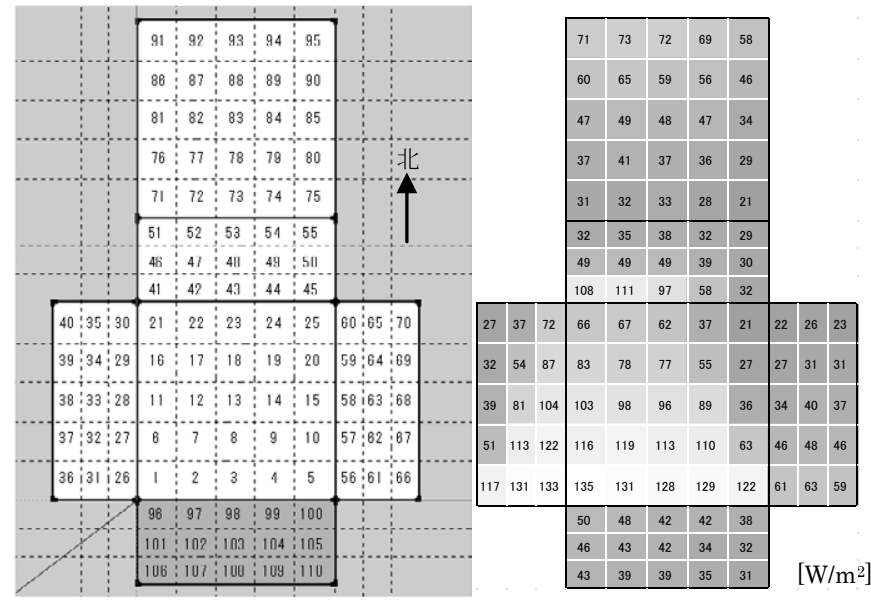

図14 110の面要素と1月2日10時の侵入日射分布図
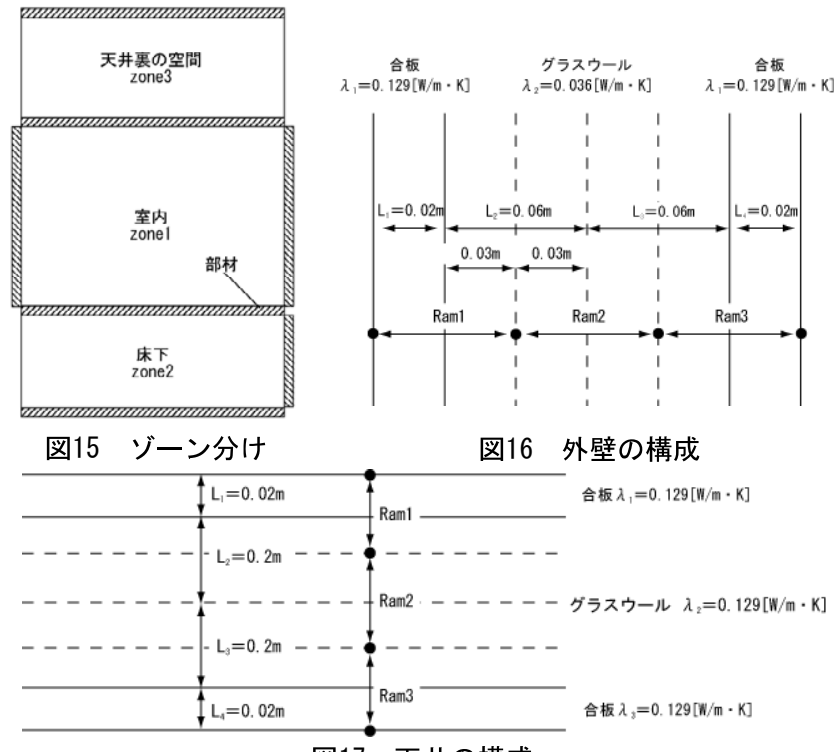

図17 天井の構成

表4 モデルの熱貫流抵抗

\begin{tabular}{|c|c|c|c|c|}
\hline \multirow{4}{*}{$\begin{array}{l}\text { 熱貫流抵抗 } \\
{\left[\mathrm{m}^{2} \cdot \mathrm{K} / \mathrm{W}\right]}\end{array}$} & 床(合板 $30 \mathrm{~mm}$ ) & $\begin{array}{l}\text { 床(コンクリート } 100 \mathrm{~mm} \\
\text { +断熱材 } 500 \mathrm{~mm} \text { ) }\end{array}$ & $\begin{array}{c}\text { 床(コンクリート } \\
\text { +断熱材 } 500 \mathrm{~mm} \text { ) }\end{array}$ & 基礎壁 \\
\hline & 0.2 & 14.0 & 13.9 & 2.8 \\
\hline & 天井 & 屋根 & 外壁 & 床下 \\
\hline & 11.4 & 3.4 & 3.6 & 3.3 \\
\hline
\end{tabular}




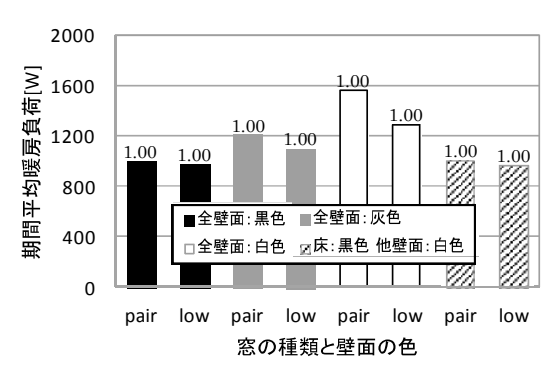

図18 空1、Rss0.5

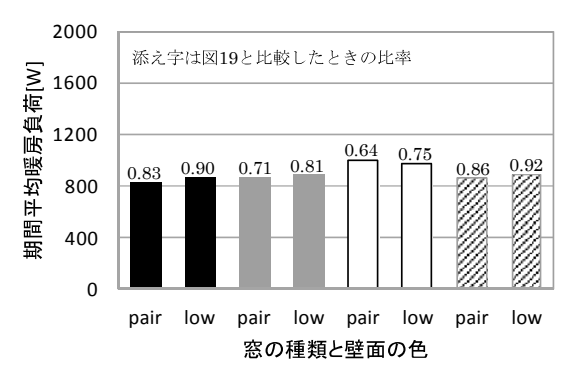

図19 空2、Rss0. 5

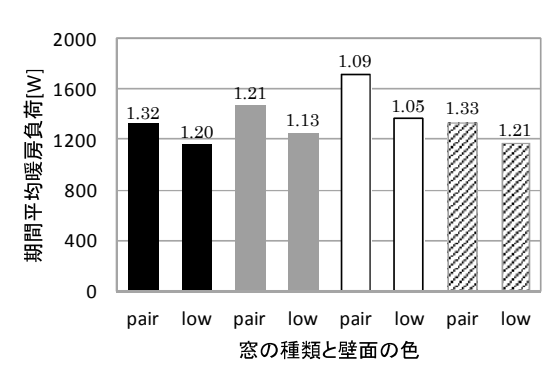

図20 空1、Rss0.7

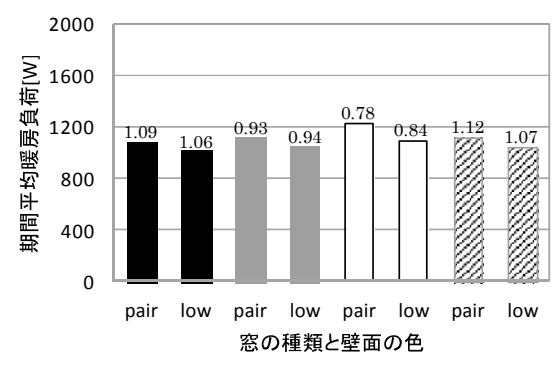

図21 空2、Rss0.7

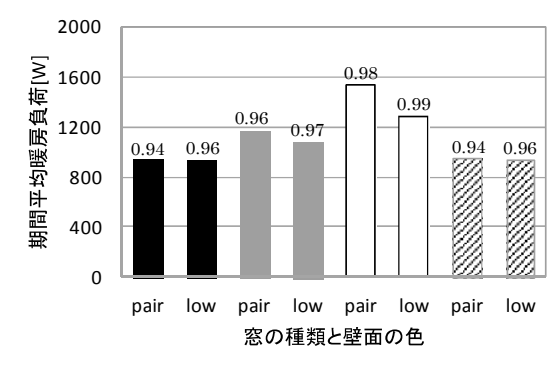

図22 空1、Rss0.9

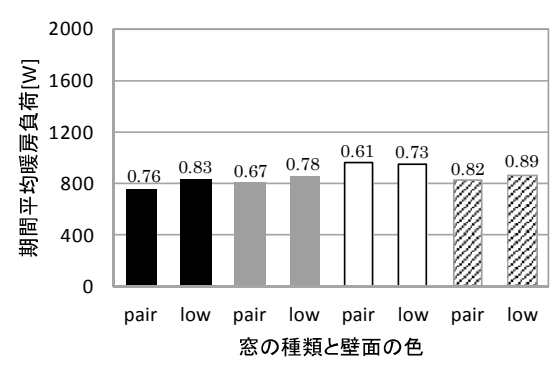

図23 空2、Rss0.9
量は波長域を分けたマルチバンドによる計算より精度の高い透過日 射量を評価できる。なお、マルチバンドによる計算を考える際、内 壁の波長域別反射率は一律で計算を行った。

\section{5 有限体積法}

詳細計算時には図15に示すようなゾーン分けを行い有限体積法を 使用し計算を行った。図16に作成したモデルの外壁の構成を示し、 図17に天井の構成を示す。領域を4個のコントロールボリュームに 分割し、基礎床、屋根、床下、ガラスも同様の分割方法をとった。 表4 亿各面の熱貫流抵抗を示す。床面は熱容量の異なる 3 種類作成

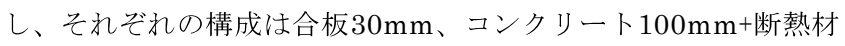
$500 \mathrm{~mm}$ (以下コンクリート $100 \mathrm{~mm}$ ) 、コンクリート $200 \mathrm{~mm}+$ 断熱 材 $500 \mathrm{~mm}$ (以下コンクリート $200 \mathrm{~mm}$ ) とした。

\section{6 解析結果と考察}

図18-23は南側天空率（Rss0.5、0.7、0.9の3通り）と空の形状 (空1と空 2 の 2 通り) 、ガラスの種類（ペアガラスとLow-eガラス の2通り）、壁面の色（壁面全てが黒色、壁面全てが灰色、壁面全 てが白色、床面が黒・他壁面が白の 4 通り）、を因子に 1 月 4 日 3 月 30 日までの期間平均暖房負荷を求めた図である。このとき床は 合板 $30 \mathrm{~mm}$ を使用している。

図18についてペアガラスとLow-eガラスを比較すると、ペアガラ スの方が期間平均暖房負荷が高いことが確認出来る。また色が白色 へ近づくにつれてペアガラスの期間平均暖房負荷が高く、黒色へ近 づくにつれてペアガラスとLow-eガラスの期間平均暖房負荷が小さ くなることが確認出来る。これは壁の色が白へ近づくほど反射に よって室外一日射が出ていくことが原因であると考えられる。ま た、ペアガラス実装かつ全壁面白に対し、ペアガラス実装かつ全壁 面黒色の期間平均暖房負荷は $64 \%$ であり壁面の色が暖房負荷に与 える影響が小さくないことが分かった。

図18、19からRss0.5の空1と空2を比べると空面積の小さい空 2 の 方が期間平均暖房負荷は小さくなることが確認出来、全壁面黒色の ときペアガラスで $83 \%$ 、Low-eガラスで $90 \%$ 、全壁面白色のときぺ アガラスで $64 \%$ 、Low-eガラスで75\%であった。

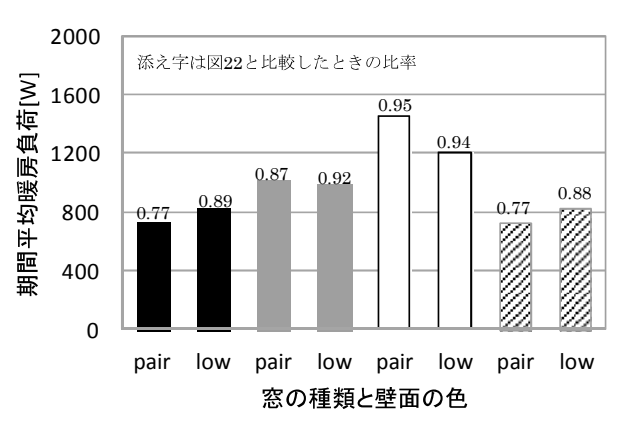

図24 空1、Rss0.9、

（床面コンクリート $100 \mathrm{~mm}$ )

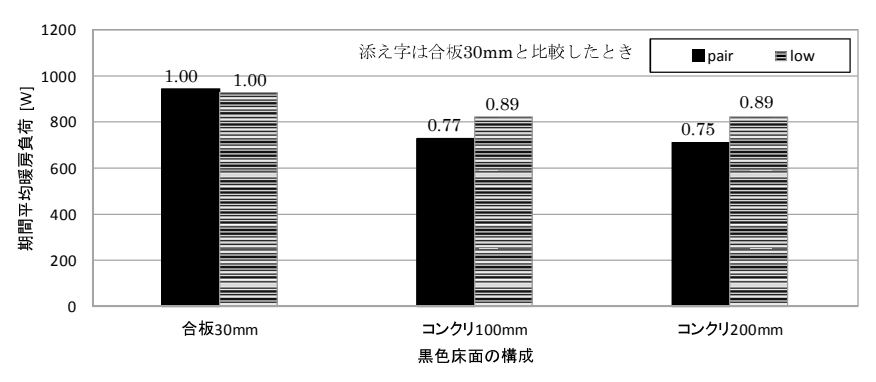

図25 空1、Rss0.9、全面黒色

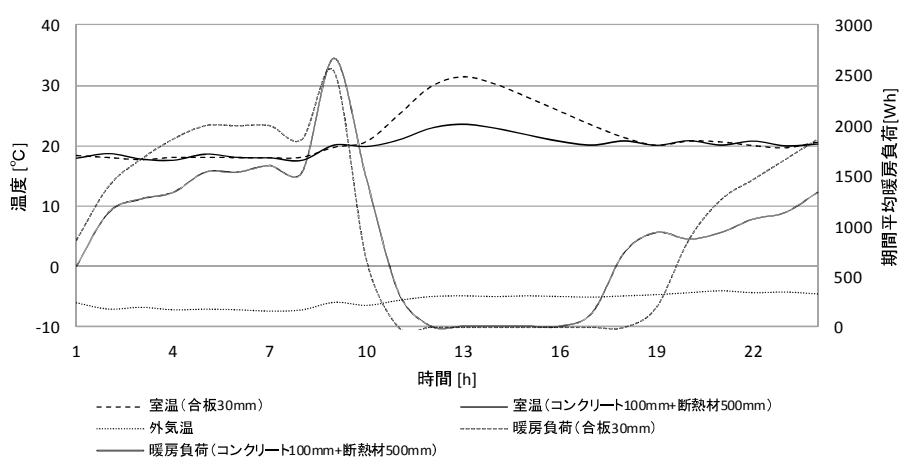

図26 空1、Rss0. 9、全面黒色 
図18-23から空 1 、2に共通してRss0.5から 0.9 一上昇寸ると期間平 均暖房負荷は微減することが確認出来、空 10 とき平均 $96 \%$ 、空 2 のとき平均 $95 \%$ に減少した。空 $1 、 2$ に共通してRss0.7はRss0.5に 比べ期間平均暖房負荷が上昇している。これはRssが天空率を示す もので、図7-9上で比較するとRss0.7とはいえモデル周囲に存在す る多くの建物が侵入日射に影響していると考えられる。

図24は図 22 の床面を合板 $30 \mathrm{~mm}$ からコンクリート $100 \mathrm{~mm}$ 一変更 し熱容量を加えた際の解析結果であり、暖房負荷の減少が確認出来 る。図22に比べ全壁面黒色ペアガラス実装で $77 \%$ 、全壁面白色ペ アガラス実装で $95 \%$ に削減された。壁面が黒に近いほど床面での 日射吸収が大きく暖房消費量に大きく影響することが確認出来た。

図25に空1、Rss0.9、壁面全てが黒色を基本とし床の構造を合板

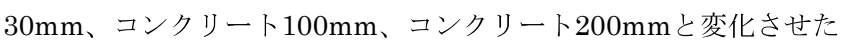
ときの日平均暖房負荷を示す。ペアガラス実装時をみると、合板 $30 \mathrm{~mm}$ 、コンクリート $100 \mathrm{~mm}$ 、コンクリート $200 \mathrm{~mm}$ と熱容量を増 加させると日平均暖房負荷が減少する傾向が確認出来る。コンク リート $100 \mathrm{~mm}$ と $200 \mathrm{~mm}$ の差は小さく Low`eガラス実装時も傾向と

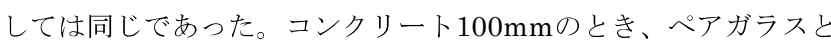
Low-eガラスの日平均暖房負荷を比べるとペアガラスのほうが日平 均暖房負荷が小さい結果となった。これは壁面が全て黒色で熱容量 も設置しているため床面に効率的に日射を吸収したためと考えられ る。設計時に日平均暖房負荷の減少のみを考えるのであれば壁面を 黒く、熱容量はコンクリート $100 \mathrm{~mm}$ 程度が良いといえる。

図26は1月 6 日を一例に、室温と暖房負荷を熱容量の有無別に比 較したものである。床が合板 $30 \mathrm{~mm}$ のきは室温が最大で $31^{\circ} \mathrm{C} 、 コ$

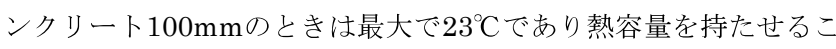
とで室温の上昇を防いでいた。

\section{4. 期間平均暖房負荷と室内の見え方}

前節では暖房負荷と壁面の色について解析を行ったので、本節で は暖房負荷に加え室内の見え方を考慮した設計方法を考える。図 27 Rss 0.5 のきの室内の見え方であり、空面から外の建物が再

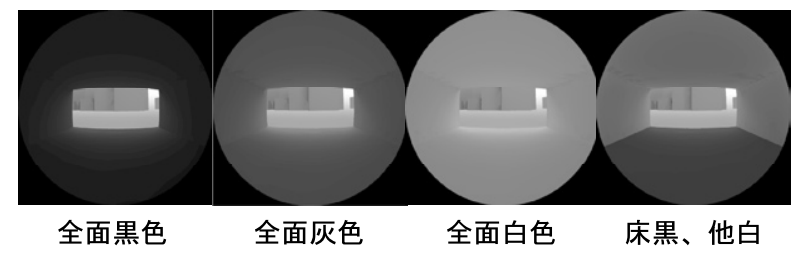

図27期間平均暖房負荷と見え方の関係

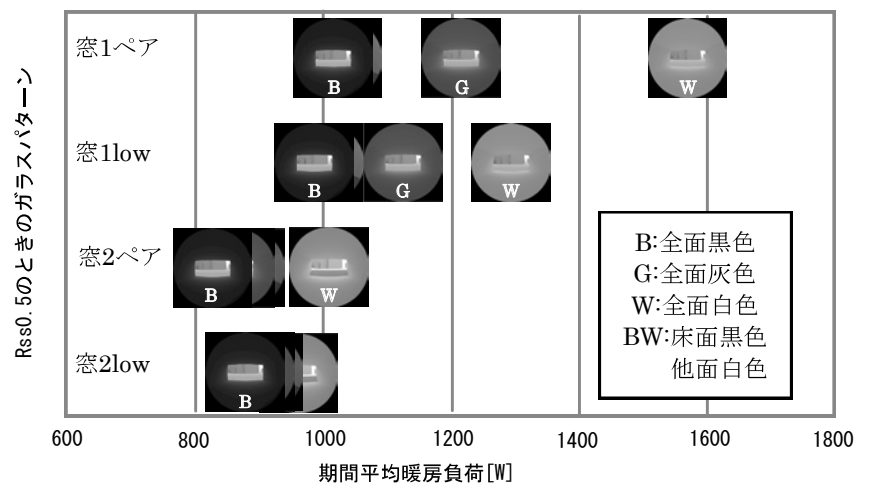

図28＼cjkstart期間平均暖房負荷と見え方の関係
現出来ていることが確認出来る。全壁面黒色は暖房負荷の削減に与 える影響が大きく、省エネルギーのみを考えるのであればこの選択 が一番効果が高い。しかし天井を高く、部屋を広く見せ、開放的な 印象にする場合には適しているとは言い難い。全壁面が白色の場合 モダンでシャープな印象を与えやすいが暖房負荷の観点からすると 不利であることがわかる。全壁面灰色はその中間に位置し、床面黒 色他面白色のパターンと比べると暖房負荷の観点から同様の性能と なることが伺える。図28にRss=0.5のときのガラスパターンと期間 平均暖房負荷と室の見え方の関係を示す。期間平均暖房負荷を $1000 \mathrm{~W}$ 付近に保とうとすると空1ペアガラス実装では部屋は黒色系 統になるが、空 2 の形状を選択すると白色系に変更することが出 来、設計者の好みに合わせて色の選択を行うことが出来る。大きな 空1で室内を白色の設計としたいとき、空をLow-eガラスに変更す る予算と期間平均暖房負荷の増大をどの程度許容出来るかで選択肢 が絞られる。空1の大きさの設計を考える際には部屋の色を黒色系 にすることでペアガラスとLow-eガラスの差が小さくなる点も確認 出来た。

\section{5. おわりに}

本研究では札幌における高断熱住宅を対象にし、南側天空率を用 いてDSGの設計判断基準を求めた。その後、周囲の建物の影響、壁 面の色、ガラスの種類の組み合わせを因子に解析を加えた。得られ た結果を以下にまとめる。

（1）ある敷地において、南側天空率（Rss）を測定するだけでDSG 効果を使用寸るに值する敷地であるか判定出来る設計閾值を求め、 札幌市ではRss=0.4であった。

（2）GISを使用して周辺建物を作成する際、侵入日射量一影響する 建物半径の閾值が $200 \mathrm{~m}$ であることが分かった。

（3）Birdモデルによる波長別日射量、GISを用いた周辺建物の影響 を考慮しThree-phase methodを使用してDSG効果が暖消費量に与え る影響を示した。壁面が黒色であること、Rssが大きいことが期間 平均暖房負荷を減少させる要因であることが分かった。

（4）室内の見え方と期間平均暖房負荷の関係示すことでDSG効果を 考える際の設計資料を作成した。

\section{謝辞}

本研究において武政孝司にRadianceの使用法を、今野雅にGIS データの取り扱いについて助言を頂きました。ここに記して感謝致 します。 
注

注1）参考に実際の札幌市の住宅地において、Rssがどの程度になるのかを図2 9 に示す。(1)の地点でRss=0.6、(5)の地点でRss=0.9である。(5)の地点は敷 地の南側に公園があるため、Rssが大きな值をとっている。

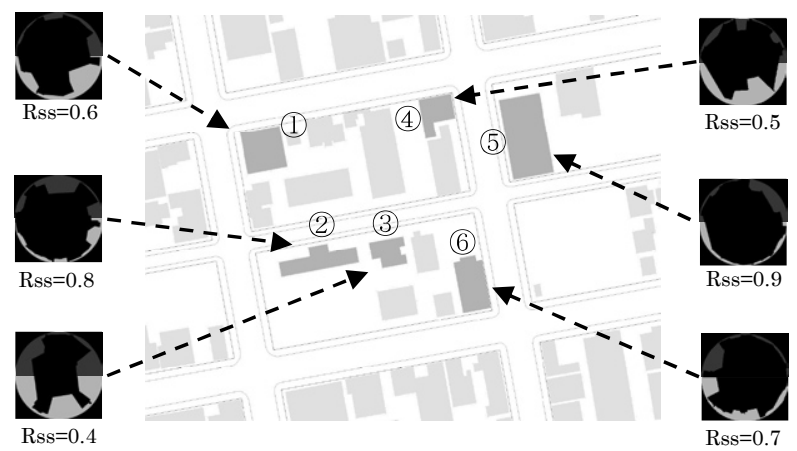

図29札幌市の住宅地におけるRssの値

注2）図4～図6は札幌市におけるDSG判定の根拠図であるが、北海道釧路市に ある白糠町において、同様の手法を用いてRssと日平均熱取得と日平均熱損 失の関倸性を図30に示す。札幌と同様に日平均熱取得と熱損失の近似式の 交点が約 0.4 であることが確認できる。
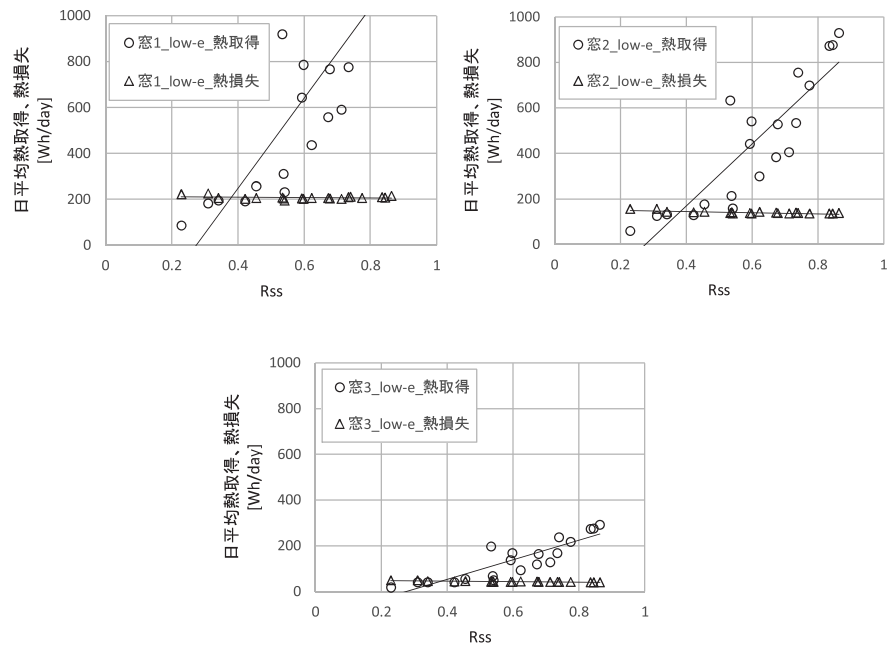

図30 白糠町におけるDSG判定

\section{参考文献}

1）小玉祐一郎、武田仁、高間三郎：ダイレクトゲインシステムの計画とシ ミュレーションその1、日本建築学会大会学術講演梗概集、計画系、55（環 境工学) pp. 399-400、1980.9

2）伊藤直明、須永修通、山崎勝弘：ダイレクトゲインシステムにおける熱容 量と補助暖房エネルギー消費量に関する研究 その1 テストセルによる間 欠暖房時の検討、日本建築学会大会学術講演梗概集、D-環境工学、pp. 997998、1985. 10

3）河合英徳、浅輪貴史、梅干野泉：建築外部空間の熱放射環境がダイレクト ゲインシステムの性能に及ぼす影響の数值解析、日本建築学会環境系論文 集、第78巻、第693号、pp. 841-848、2013.11

4) M.M.E.van Ech, R.H.J.Looman, G.J. de Bruin-Hordijk : The effect of urban and building design parameters on solar access to the urban canyon and the potential for direct passive solar heating strategies,Rnergy and Buildings 47 (2012)189-200

5) Ahmed S. Muhaisen, Mohamed B Gadi : Effect of courtyard proportions on solar heat gain and energy requirement in the temperate climate of Rome,Building and Environment 41(2006)245-253
6）大沢飛智、演田裕章、緒形浩佑、森太郎、羽山広文、菊田弘輝: 都市計画基礎 調査データを用いた建築環境シシュレーション その 2 Energy Plusを用いたダイレ クトソーラーゲイン効果の解析、空気調和・衛生工学会北海道支部第48回学術講 演論文集、pp. 35-38、2014.3

7) 日本建築学会 : Expanded ANeDAS Weather Data、社団法人日本建築学会、 2003. 2.28

8) EnergyPlusのWebサイト

〈http://apps1.eere.energy.gov/buildings/energyplus/〉(2014.3.19参照)

9) Birdモデルについて

〈http://rredc.nrel.gov/solar/models/spectral/>(2014.3.19参照)

10) 田中俊六、武田仁、土屋喬雄、岩田利枝、寺尾道仁: 最新建築環境工学[改 訂3版].株式会社井上書院.2009.8.10

11) Radiance:Three-phase methodについて

〈http://www.radiance-online.org/learning/tutorials/Tutorial-ThreePhaseMethod. pdf $>(2014.3 .19$ 参照 $)$ 


\title{
STUDY ON DESIGN METHOD OF HOUSING WITH DIRECT SOLAR HEAT GAIN BY USING GIS DATA IN COLD REGIONS
}

\author{
Kosuke OGATA*, Taro MORI ${ }^{* *}$, Hisato OSAWA***, \\ Hiroaki HAMADA***, Hirofumi HAYAMA**** and Koki KIKUTA***** \\ * Obayashi Corporation, M. Eng. \\ ** Assoc. Prof., Faculty of Eng., Hokkaido Univ., Dr. Eng. \\ *** Graduate Student, Graduate School of Eng., Hokkaido Univ. \\ **** Prof., Faculty of Eng., Hokkaido Univ., Dr. Eng. \\ ***** Assist. Prof., Faculty of Eng., Hokkaido Univ., Dr. Eng.
}

\begin{abstract}
Introduction
Many researches on direct solar gain (DSG) had been conducted during 1970's and 1980's in Japan. The experiments and numerical analyzes on a window and an install place of heat capacity to absorb much solar radiation were conducted by Ito and Kodama. Ito clarify an relationship between a DSG effect and heating cost. Although, those results are obtained with the model without any solar obstacle. Designer and engineer who use those result should be aware that an effect of DSG doesn't work under an situation in urban area where has many high rise building. In this study, 1st, we make the design flow chart for DSG, Fig. 1, 2nd, we suggest the criteria of DSG from the result of Energy-plus with climate data generated by the Japanese standard climate data with GIS data, 3rd, we conduct the detail analysis with 3 phase method of Radiance.
\end{abstract}

Design method for direct solar gain

Fig.1 shows the flow chart to design DSG effect. DSG is effective when heat gain is bigger than heat loss at a window. Numerical analyses are conducted by using Energy-plus and Japanese standard climate data with GIS data. The climate data is calculated by the method as follows. 1st, Orthographic image of building around a site is drawn by using GIS data. 2nd, the image is combined with sun position diagram. 3rd, climate data for Energy-plus can be calculated with the result and the standard climate data. Fig.4 to 6 shows the result of the numerical analysis by using Energyplus and the climate data. Heat losses are bigger than heat gain in the left side of the figure. Heat gains are bigger in the right side. The intersections of the lines of heat gain with the lines of heat loss are located around Rss $=0.4$ in every case. It indicates that Rss, sky factor in south direction, can be used as the criteria of DSG. Also the value is located at Rss $=0.4$.

Detail analysis on DSG

Detail analyzes are conducted in the cases of Rss $>0.4$ which is suitable for DSG. The 3 phase method of radiance that calculate solar radiation on a point is used to obtain solar radiation. The Japanese standard climate data divide into VIS and NIR by Bird's model to evaluate an difference of low-e glazing and double glazing. Air temperatures, surface temperatures and heating energy are simulated by using control volume method. The parameters of the simulation are area of window, panel of window, color of inside wall and heat capacity.

\section{Result and discussion}

The results indicates that heating energy is smaller when window area is small, but heating energy is biggest when window is smallest. Also, the heating energy in the case of low-e glass is smaller than the case of double glazing. Those results are different with the result to use calculating the criteria. The distributions of the solar radiation would makes the difference. It indicates that detail calculation is needed to get accurate results. Heating energy is biggest in the case that color of inside wall is white, because reflected radiation come back to outside. Heating energy is smaller when heat capacity is big. But the effect isn't bigger when the thickness of heat capacity is over $10 \mathrm{~cm}$. 